Global Talent 
Studies of the Walter H. Shorenstein Asia-Pacific Research Center

Andrew G. Walder, General Editor

The Walter H. Shorenstein Asia-Pacific Research Center in the Freeman Spogli Institute for International Studies at Stanford University sponsors interdisciplinary research on the politics, economies, and societies of contemporary Asia. This monograph series features academic and policy-oriented research by Stanford faculty and other scholars associated with the Center. 
ALSO PUBLISHED IN THE

SHORENSTEIN ASIA-PACIFIC RESEARCH CENTER SERIES

Failed Democratization in Prewar Japan: Breakdown of a Hybrid Regime Harukata Takenaka (2014)

New Challenges for Maturing Democracies in Korea and Taiwan

Edited by Larry Diamond and Gi-Wook Shin (2014)

Spending Without Taxation: FILP and the Politics of Public Finance in Japan

Gene Park (20II)

The Institutional Imperative: The Politics of Equitable Development in Southeast Asia

Erik Martinez Kuhonta (20II)

One Alliance, Two Lenses: U.S.-Korea Relations in a New Era

Gi-Wook Shin (20IO)

Collective Resistance in China: Why Popular Protests Succeed or Fail Yongshun Cai (2010)

The Chinese Cultural Revolution as History

Edited by Joseph W. Esherick, Paul G. Pickowicz, and Andrew G. Walder (2006)

Ethnic Nationalism in Korea: Genealogy, Politics, and Legacy

Gi-Wook Shin (2006)

Prospects for Peace in South Asia

Edited by Rafiq Dossani and Henry S. Rowen (2005) 



\section{Global Talent}

SKILLED LABOR AS SOCIAL CAPITAL IN KOREA

Gi-Wook Shin and Joon Nak Choi

Stanford University Press

Stanford, California 
Stanford University Press

Stanford, California

(C) 2015 by the Board of Trustees of the Leland Stanford Junior University.

All rights reserved.

No part of this book may be reproduced or transmitted in any form or by any means, electronic or mechanical, including photocopying and recording, or in any information storage or retrieval system without the prior written permission of Stanford University Press.

Printed in the United States of America on acid-free, archival-quality paper

Library of Congress Cataloging-in-Publication Data

Shin, Gi-Wook, author.

Global talent : skilled labor as social capital in Korea / Gi-Wook Shin and Joon Nak Choi.

pages $\mathrm{cm}$-(Studies of the Walter H. Shorenstein Asia-Pacific Research Center) Includes bibliographical references and index.

ISBN 978-o-8047-9349-o (cloth : alk. paper)—

ISBN 978-0-8047-9433-6 (pbk. : alk. paper)

I. Foreign workers-Korea (South) 2. Skilled labor-Korea (South) 3. Social capital (Sociology)-Korea (South) 4. Human capital-Korea (South) 5. TransnationalismEconomic aspects-Korea (South) 6. Globalization-Economic aspects-Korea (South) I. Choi, Joon Nak, I977- author. II. Title. III. Series: Studies of the Walter H. Shorenstein Asia-Pacific Research Center.

$$
\begin{aligned}
& \text { HD8730.5.S45 20I5 } \\
& 331.6^{\prime} 2095195-\mathrm{dc} 23
\end{aligned}
$$

2014035015

ISBN 978-0-8047-9438-I (electronic)

Typeset by Newgen in II/I4 Garamond 